\title{
How to Measure the Financial Health?
}

\author{
Dafid Richi Setiawan, Sri Handayani* \\ Universitas Teknologi Yogyakarta \\ Yogyakarta, Indonesia \\ *srih2488@gmail.com
}

\begin{abstract}
This study aims to determine the level of the financial health of company. The data analysed is the company's financial statement data for the 2015-2017 period of PT Perkebunan Nusantara VII. The results of the analysis of the ratio of the company's health level shows is not healthy with a weight of 21.25 . In 2016 the results were unhealthy with a weight of 15.25. In 2017 getting unhealthy results with a weight of 14 .
\end{abstract}

\section{Keywords—financial performance, financial health}

\section{INTRODUCTION}

In accordance with the previous background, the researchers are interested in knowing the level of financial health of PT. Perkebunan Nusantara VII as seen from the 20152017 company financial statements based on Decree of the Minister of Indonesia State-Owned Enterprises Number: Kep100 / Mbu / 2002 [1] concerning the evaluation.

TABLE I. PROFIT/LOSS ON 2015-2017

\begin{tabular}{|l|l|}
\hline \multicolumn{1}{|c|}{ Year } & \multicolumn{1}{c|}{ Profit/loss } \\
\hline 2015 & Rp. 46.369 .719 .458 \\
\hline 2016 & Rp. -547.210 .138 .113 \\
\hline 2017 & Rp. -180.364 .749 .424 \\
\hline \multicolumn{2}{|c|}{ Source: Financial data of PT. Perkebunan Nusantara VII }
\end{tabular}

The contribution of the results of this study is expected to provide benefits in the consideration of companies to improve company health at PT. Perkebunan Nusantara VII from a financial aspect. In addition, this research is expected to be one of the information to find out some financial problems that occur in companies.

The purpose and objectives of establishing BUMN concerning State Owned Enterprises is to contribute to the development of the national economy [2].

\section{LITERATURE REVIEW}

\section{A. Ratio Analysis}

Liquidity is the ability of a company to be able to provide liquid instruments in such a way that it can meet its financial obligations when billed [3].
- Current ratio

$\mathrm{CR}=\frac{\text { Current assets }}{\text { Current debt }}$

- Cash ratio

Cash Ratio $=\frac{\text { Cash }+ \text { securities }}{\text { Current debt }}$

- Total asset turnover

$\mathrm{TATO}=\frac{\text { net sales }}{\text { total assets }}$

- Average collection period

$\mathrm{CP}=\frac{\text { average receivables } \mathrm{X} 360}{\text { credit sales }}$

- Inventory turnover

IT $=\frac{\text { Cost of Goods Sold }}{\text { Average Inventory }}$

According to Kasmir [4] profitability ratios are ratios to assess a company's ability to get profits.

- Return on equity

$$
\mathrm{ROE}=\frac{\text { Earning after Tax }}{\text { total equity }}
$$

- Return on investment

ROI $=\frac{\text { Earning after tax }}{\text { Total Assets }}$

- Solvability ratio

According to [4], solvency is the company's ability to fulfil all financial obligations if the company is liquidated.

- Debt to assets ratio

$\mathrm{DAR}=\frac{\text { total Debt X100\% }}{\text { Total Asset }}$

B. Company Health Classification

The soundness of a BUMN company is classified as: 
TABLE II. ClassIFICATION OF COMPANY HEALTHY [1]

\begin{tabular}{|l|l|}
\hline \multicolumn{1}{|c|}{ Classification } & \multicolumn{1}{c|}{ Score } \\
\hline HEALTHY & if the total score $>65$ \\
\hline UNHEALTHY & if the total score $30-65$ \\
\hline NOT HEALTHY & if the total score $<30$ \\
\hline
\end{tabular}

\section{METHODS}

The sample used in this study is the 2015-2017 financial statements.

TABLE III. DEFINITION OF OPERATIONAL VARIABLES

\begin{tabular}{|c|c|c|}
\hline Variable & Concept Variable & Scale \\
\hline ROE (X1) & $\begin{array}{l}\text { Measuring how efficiently a company } \\
\text { uses money from shareholders to make } \\
\text { profits and grow the company }\end{array}$ & Ratio \\
\hline ROI (X2) & $\begin{array}{l}\text { This ratio shows the results of all assets } \\
\text { under control regardless of funding } \\
\text { sources }\end{array}$ & Ratio \\
\hline Cash Ratio (X3) & $\begin{array}{l}\text { This ratio calculates a company's ability } \\
\text { to repay short-term debt with available } \\
\text { cash }\end{array}$ & Ratio \\
\hline $\begin{array}{ll}\begin{array}{l}\text { Current } \\
\text { (X4) }\end{array} & \text { Ratio } \\
\end{array}$ & $\begin{array}{l}\text { This ratio shows the company's ability to } \\
\text { meet short-term debt obligations }\end{array}$ & Ratio \\
\hline $\begin{array}{l}\text { Collection period } \\
\text { (X5) }\end{array}$ & $\begin{array}{l}\text { This ratio measures the average time it } \\
\text { takes a company to collect each } \\
\text { receivable }\end{array}$ & Ratio \\
\hline $\begin{array}{l}\text { Inventory } \\
\text { Turnover (X6) }\end{array}$ & This ratio measures inventory efficiency & Ratio \\
\hline $\begin{array}{l}\text { Total Asset } \\
\text { Turnover (X7) }\end{array}$ & $\begin{array}{l}\text { This ratio measures a company's ability } \\
\text { to generate sales from total assets by } \\
\text { comparing net sales with average total } \\
\text { assets }\end{array}$ & Ratio \\
\hline $\begin{array}{l}\text { Debt to Assets } \\
\text { Ratio (X8) }\end{array}$ & $\begin{array}{l}\text { This ratio shows the importance of the } \\
\text { source of loan capital and the level of } \\
\text { security held by creditors }\end{array}$ & Ratio \\
\hline $\begin{array}{l}\text { Company health } \\
\text { level (Y) }\end{array}$ & $\begin{array}{l}\text { See whether a financial within the } \\
\text { company is in good health or not }\end{array}$ & Weight \\
\hline
\end{tabular}

The data analysis method used is a quantitative descriptive method. In this study, the analysis was carried out by analysing the financial statements of PT. Perkebunan Nusantara VII using Ratio analysis according to BUMN [1] concerning BUMN health assessment.

\section{RESULTS AND DISCUSSION}

\section{A. Result}

TABLE IV. WEIGHT ASSESSMENT OF PERFORMANCE INDICATORS FROM BUMN PTPN VII 2015

\begin{tabular}{|l|l|l|}
\hline \multicolumn{2}{|c|}{ Assessment of the Weight of Types of Indicators in 2015 } \\
\hline \multicolumn{1}{|c|}{ Indicator } & \multicolumn{1}{c|}{ Result } & Weight \\
\hline ROE & $1,232 \%$ & 4 \\
\hline ROI & 0,356 & 2 \\
\hline Cash Ratio & $7,639 \%$ & 1 \\
\hline Current Ratio & $62,727 \%$ & 0 \\
\hline Collection Periods & 1 day & 5 \\
\hline Inventory Turnover & 572 days & 0 \\
\hline Total Asset Turnover & 33,932 & 2 \\
\hline Debt to Assets Ratio & $28,872 \%$ & 7,25 \\
\hline Total & \multicolumn{2}{|l}{21,25} \\
\hline explanation & if the total score $30=$ Not healthy \\
\hline Result & Not healthy \\
\hline
\end{tabular}

The total weight from the ratio calculation used to see the level of company health at PT Perkebunan Nusantara VII in 2015 was 21.25 with not healthy results.

TABLE V. WEIGHT ASSESSMENT OF PERFORMANCE INDICATORS FROM BUMN PTPN VII 2016

\begin{tabular}{|l|l|l|}
\hline \multicolumn{3}{|c|}{ Assessment of the Weight of Types of Indicators in 2016} \\
\hline Indicator & \multicolumn{1}{c|}{ Result } & Weight \\
\hline ROE & $-21,488 \%$ & 0 \\
\hline Cash Ratio & $-4,622 \%$ & 1 \\
\hline Current Ratio & $1,012 \%$ & 0 \\
\hline Collection Periods & 31,789 & 0 \\
\hline Inventory Turnover & 1 day & 5 \\
\hline Total Asset Turnover & 674 days & 0 \\
\hline Debt to Assets Ratio & $27,544 \%$ & 2 \\
\hline Total & $21,552 \%$ & 7,25 \\
\hline explanation & if the total score $30=$ Not healthy \\
\hline Result & Not healthy \\
\hline
\end{tabular}

The total weight of the ratio calculation used to see the level of company health at PT Perkebunan Nusantara VII in 2016 was 15.25 with not healthy results.

TABLE VI. WEIGHT ASSESSMENT OF PERFORMANCE INDICATORS FROM BUMN PTPN VII 2017

\begin{tabular}{|l|l|l|}
\hline \multicolumn{2}{|c|}{ Assessment of the Weight of Types of Indicators in 2016 } \\
\hline \multicolumn{1}{|c|}{ Indicator } & \multicolumn{1}{c|}{ Indicator } & \multicolumn{1}{c|}{ Indicator } \\
\hline ROE & $-8,834 \%$ & 0 \\
\hline ROI & $-1,488 \%$ & 1 \\
\hline Cash Ratio & $3,632 \%$ & 0 \\
\hline Current Ratio & $25,863 \%$ & 0 \\
\hline Collection Periods & 1 day & 5 \\
\hline Inventory Turnover & 388 days & 0 \\
\hline Total Asset Turnover & $22,141 \%$ & 2 \\
\hline Debt to Assets Ratio & $16,848 \%$ & 6 \\
\hline Total & \multicolumn{2}{|l}{} \\
\hline explanation & if the total score 30 Not healthy \\
\hline Result & Not healthy \\
\hline
\end{tabular}

The total weight of the ratio calculation used to see the level of company health at PT Perkebunan Nusantara VII in 2017 is 14 with not healthy results

\section{B. Discussion}

Based on the results in 2016 PT Perkebunan Nusantara VII experienced a decrease in total weight by 6 due to a decrease in ROE of 2, ROI of 1 and a cash ratio of 1 while in 2017 the total breakdown again decreased by 1.25 pliers caused by a decrease in the ratio of own capital of total assets, and when observed the total weights from 2015-2017 continued to decline.

\section{CONCLUSION}

The health of the company which was reviewed through the financial aspects of the financial statements at PT Perkebunan Nusantara VII, namely: 1) In 2015 getting not healthy results with a weight of $21.25,2$ ) In 2016 getting not healthy results 
with a weight of 15.25, and 3) In 2017 getting not healthy results with a weight of 14 .

\section{REFERENCES}

[1] Decree of the Minister of Indonesia State-Owned Enterprises Number: Kep-100 / Mbu / 2002, Concerning the Assessment of the Health Level of State-Owned Enterprises, 2002.
[2] Law No. 19 of 2003 concerning Indonesia State-Owned Enterprises.

[3] B. Riyanto, Fundamentals of Company Spending. Fourth Edition. Yogyakarta: BPFE, 2010.

[4] K. Kasmir, Financial Statement Analysis. Seventh edition one. Jakarta : PT Raja Grfindo Persada, 2011. 